\title{
STABILITY OF SPERMATOZOAL DEOXYRIBONUCLEO- PROTEIN DURING PASSAGE THROUGH THE BOVINE EPIDIDYMIS
}

\author{
B. L. GLEDHILL* AND R. P. AMANN \\ School of Veterinary Medicine, University of Pennsylvania, \\ New Bolton Center, Kennett Square, Pa. 19348, U.S.A., and \\ Dairy Breeding Research Center, \\ The Pennsylvania State University, University Park, \\ Pa. 16802, U.S.A.
}

(Received 7th December 1972)

Earlier studies evaluating the condensation of chromatin during spermiogenesis revealed that deoxyribonucleoprotein (DNP) becomes more resistant to thermal denaturation as the round spermatid elongates and assumes the shape of a mature spermatozoon (Ringertz, Gledhill \& Darżynkiewicz, 1970). Unfortunately, only heterogeneously aged populations of cells, represented by spermatids in loosely defined categories and at differing intervals before release from the germinal epithelium, could be studied. Homogeneous preparations of spermatozoa leaving the testis were unavailable. Because the 'testicular spermatozoa' group evaluated by Ringertz et al. (1970) was a mixture of spermatids and spermatozoa, it was not possible to determine if final stabilization of germ-cell DNP occurs during the latter phases of spermiogenesis or in the caput epididymidis. From the data for two bulls, Gledhill (1972) suggested that the thermal denaturation profile for spermatozoa removed from the caput epididymidis was different from that for cells obtained from the ductus deferens. He suggested, therefore, that the molecular rearrangement of spermatozoal DNP is largely completed in the upper portion of the epididymis. The availability of homogeneous populations of rete testis spermatozoa has made possible the design of a more critical study, in which the objective was to establish whether the stability of DNP in post-epididymal spermatozoa differed from that in cells entering the epididymis.

Spermatozoa from the rete testis and/or the cauda epididymidis were obtained from nine Holstein bulls of 1.7 to 8.5 years of age. Spermatozoa from the rete testis were collected through an indwelling cannula (Sexton, Amann \& Flipse, 1971; Voglmayr, Kavanaugh, Griel \& Amann, 1972) while the animal was conscious and unrestrained. Each sample represented a 15- to 60-min collection. Fresh samples of spermatozoa from the cauda epididymidis were acquired through a cannula in the proximal ductus deferens (Sexton et al., 1971) when the bull mounted a stimulus animal. Ejaculated spermatozoa also were col-

* Present address: Bio-Medical Division, Lawrence Livermore Laboratory, University of California, Livermore, California 94550, U.S.A. 
lected from six of the above bulls as well as from one Angus and two other Holstein bulls. A total of nine samples of spermatozoa from the rete testis, four samples of spermatozoa from the cauda epididymidis and nine samples of ejaculated spermatozoa were evaluated. Immediately after each sample was obtained, the spermatozoa were washed in buffer and fixed in ethanol:acetone $(1: 1, \mathrm{v} / \mathrm{v})$. Smears were made and were stored as previously described (Gledhill, Gledhill, Rigler \& Ringertz, 1966).

Thermal denaturation of nuclear DNA in the DNP of individual, morphologically normal sperm heads was measured in situ according to the acridine orange procedure described by Ringertz et al. (1970). This technique is reputed to measure the extent of denaturation by microfluorimetry of the $530-\mathrm{nm}$ and 590 -nm emissions from cells stained with acridine orange and previously heattreated at one of several temperatures between 22 and $100^{\circ} \mathrm{C}$. Double-stranded DNA is denatured and splits into single-stranded polynucleotides at higher temperatures. Acridine orange binds as a monomer to double-stranded DNA and the complex fluoresces green $\left(F_{530}=\right.$ fluorescence at $\left.530 \mathrm{~nm}\right)$ when excited by 365-nm light. Single-stranded nucleic acids and denatured DNA bind the dye as an aggregate and emit a red fluorescence $\left(\mathrm{F}_{590}\right)$ with identical excitation. With increasing denaturation of DNA, there is a shift toward red in the emission spectrum. Thermal denaturation profiles of spermatozoal DNA were constructed by plotting alpha values $\left(\alpha=F_{590} / F_{530}\right)$ against temperature (Ringertz et al., 1970).

Certain smears of spermatozoa were treated with RNase (Type III-A; Sigma Chemical Co., St Louis) before thermal denaturation to ensure that traces of RNA were not present and confounding the results. The aqueous solution $(1 \mathrm{mg} / \mathrm{ml}$ ) of RNase was immersed in boiling water for $2 \mathrm{~min}$ to inactivate any DNase and protease contamination (McDonald, 1948).

The data summarized in Text-fig. la and $b$, reveal that extraction with RNase did not alter the thermal denaturation profile of spermatozoa from the rete testis or that of spermatozoa which had traversed the epididymis. The postepididymal group included both spermatozoa from the cauda epididymidis and ejaculated spermatozoa because inspection of curves for all thirteen samples revealed no difference between cell types. Thus, heads of spermatozoa leaving the testis by way of the efferent ducts (Text-fig. la) did not contain detectable amounts of heat-labile nucleotides extractable by RNase. This conclusion supports earlier biochemical analyses of bulk samples of ejaculated bull spermatozoa (Bhargava, Bishop \& Work, 1959), ${ }^{*}$ and autoradiographic analyses of $\left[{ }^{3} \mathrm{H}\right]$ uridine-labelled mature spermatids from mice (Monesi, 1964), rams (Loir, 1972) and bulls (Loir \& Hochereau-de Reviers, 1972).

The comparison (Text-fig. 1c) between spermatozoa from the rete testis and post-epididymal spermatozoa included data for samples analysed only after RNase extraction together with data for non-extracted cells. The resistance to thermal denaturation of DNP in post-epididymal spermatozoa was no greater than that for DNP in spermatozoa leaving the rete restis. After release from the germinal epithelium, the time required for passage of spermatozoa into and through the rete testis is apparently very short. Thus, in contradiction to conclusions based on initial data (Gledhill, 1972), the increase in thermal 
stability of DNP associated with chromatin condensation (Ringertz et al., 1970) ceases at or about the time that the spermatozoa are released into the lumen of the seminiferous tubule.

The molecular rearrangements of nuclear DNP are completed while the developing spermatozoon is in the testis. Thus, in spermatozoal DNP, the

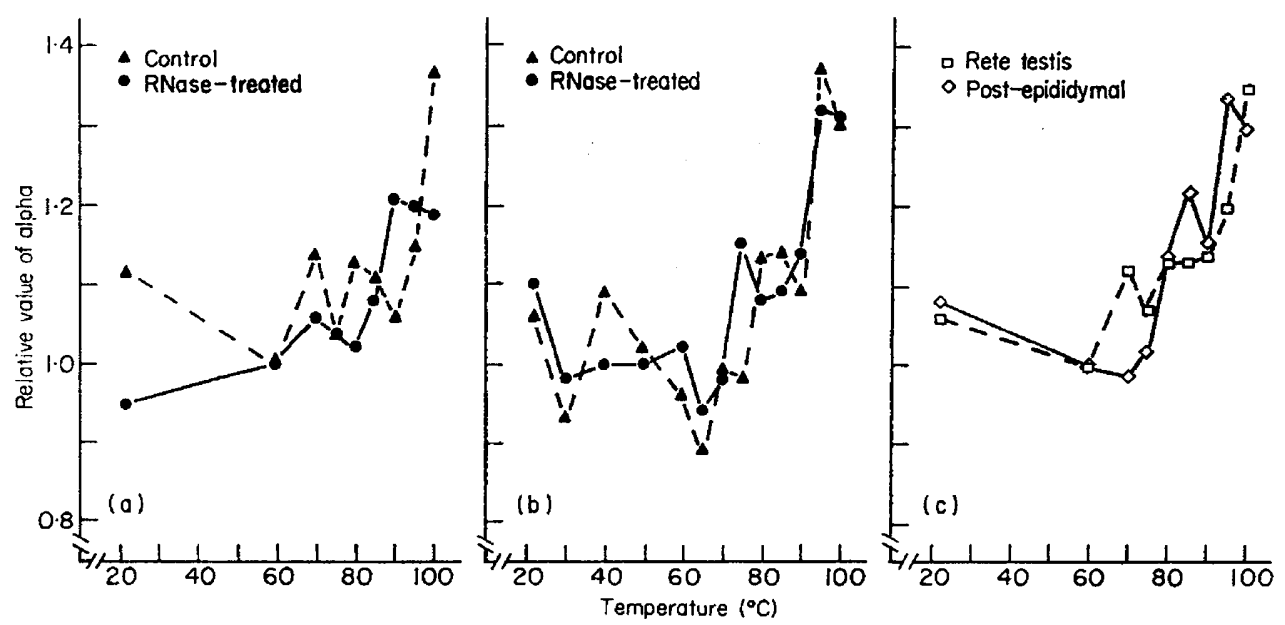

TEXT-FIG. 1. The resistance to thermal denaturation of DNP in bull spermatozoa as evaluated by the $\mathbf{F}_{590} / \mathbf{F}_{530}$ ratio (alpha) of acridine orange-stained cells. Relative values of alpha were calculated by dividing the mean absolute value for each temperature by the mean absolute value at $60^{\circ} \mathrm{G}$ for that sample. The effect of RNase extraction on the thermal denaturation of DNP in heads of (a) spermatozoa from the rete testis (control spermatozoa, six samples from five bulls; RNase-extracted spermatozoa, five samples from four bulls) and (b) post-epididymal spermatozoa (paired aliquots of two samples of spermatozoa from the cauda epididymidis and four samples of ejaculated spermatozoa were evaluated with and without $R$ Nase extraction; the relative values of alpha were calculated using the average of values for $30,40,50$ and $60^{\circ} \mathrm{C}$ as the base.) The thermal denaturation profiles (c) of spermatozoa from the rete testis (non-extracted, six samples from five bulls and RNase-extracted, three samples from three other bulls) and postepididymidal spermatozoa (non-extracted, four samples of spermatozoa from the cauda epididymidis from four bults and seven samples of ejaculated spermatozoa from seven bulls; and RNase-extracted, two samples of ejaculated spermatozoa from two other bulls). The coefficient of variation for the thirteen temperatures ranged from 10 to $26 \%$.

binding between DNA and arginine-rich protein (Gledhill et al., 1966) does not change during transport of spermatozoa through the epididymis. Further chromatin stabilization results, however, from introduction within the epididymis of disulphide groups which provide protein-to-protein cross-linking in spermatozoa (Calvin \& Bedford, 1971)

This study was supported by Grant HD-03577 from the U.S. Public Health Service and was conducted persuant to contract NIH-NICHD 69-2137. Dr J. F. Kavanaugh, Dr L. C. Griel, Jr and Dr J. K. Voglmayr performed surgery and Miss Nini A. Rosenfeld provided technical assistance.

\section{REFERENCES}

Bhargava, P. M., Brshop, M. W. H. \& Work, T. S. (1959) The chemical composition of bull semen with special reference to nucleic acids, free nucleotides and free amino acids. Biochem. $\mathcal{F} .73,242$. 
GALVIN, H. I. \& BedFoRd, J. M. (1971) Formation of disulphide bonds in the nucleus and accessory structures of mammalian spermatozoa during maturation in the epididymis. F. Reprod. Fert. Suppl. 13, 65.

GLedHILL, B. L. (1972) Further studies on the nuclear chromatin of morphologically abnormal bull spermatozoa. F. Reprod. Fert. 29, 431.

Gledhill, B. L., Gledhill, M. P., Rigler, R., JR \& Ringertz, N. R. (1966) Changes in deoxyribonucleoprotein during spermiogenesis in the bull. Expl Cell Res. 41, 652.

LorR, M. (1972) Métabolisme de l'acide ribonucléique et des protéines dans les spermatocytes et les spermatides du bélier (Ovis aries). I. Incorporation et devenir de la ${ }^{3} \mathrm{H}$-uridine. Annls Biol. anim. Biochim. Biophys. 12, 203.

Lork, M. \& Hochereau-De Reviers, M. T. (1972) Deoxyribonucleoprotein changes in ram and bull spermatids. F. Reprod. Fert. 31, 127.

MaDonald, M. R. (1948) A method for the preparation of protease free crystalline ribonuclease. F. gen. Physiol. 32, 39.

Monesi, V. (1964) Ribonucleic acid synthesis during mitosis and meiosis in the mouse testis. 7. Cell Biol. 22, 521.

Ringertz, N. R. Gledhill, B. L. \& DARżynkIEwicz, Z. (1970) Changes in deoxyribonucleoprotein during spermiogenesis in the bull. Sensitivity of DNA to heat denaturation. Expl Cell Res. 62, 204.

Sexton, T. J., Amann, R. P. \& Flipse, R. J. (1971) Free amino acids and protein in rete testis fluid, vas deferens plasma, accessory sex gland fluid, and seminal plasma of the conscious bull. $\mathcal{F}$. Dairy Sci. 54, 412.

Voglmayr, J. K., Kavanaugh, J. F., Griel, L. C., JR \& Amann, R. P. (1972) A modified technique for cannulating the rete testis of the bull. $\mathcal{F}$. Reprod. Fert. 31, 291. 